\title{
Management alternatives in national park areas: the case of llgaz Mountain National Park
}

\author{
Sevgi Öztürk \& Sezgin Ayan
}

Keywords: AHP technique, alternative management models, llgaz Mountain National Park

\section{Abstract}

National parks are the biggest and most important nature conservation systems in Turkey, but no effective protection approach has been applied in Turkey since the national park was established in 1976. Ilgaz Mountain National Park (IMNP) is a very important mountain ecosystem with its abundance of biological, natural and cultural diversity. It also has aesthetic and recreational potential and winter tourism facilities to attract a great number of visitors. But tourism policy in the area is not sustainable and there are management issues. For these reasons, all the factors and their alternatives were determined and the Analytic Hierarchy Process (AHP) method was used to find the best management alternative. The model of protection-supported usage (0.3903) emerged as the most suitable management alternative.
Profile

Protected area

Ilgaz Mountain National Park

Mountain range

Ilgaz Mountains

Country

Turkey

\section{Introduction}

Nature protection areas are significant resources which provide scientific, artistic and educational benefits and assist in the protection of natural, historical and cultural wealth. In addition they answer the recreational needs of humans and provide gene resources and biological wealth (Özbay 2008). All these qualities of protected areas attract urban people to leave behind the stress, traffic and noise experienced in cities and to turn their steps towards natural life areas.

In recent years, multidimensional decision-making techniques, which consider social preferences and their applicability, have become important in determining management strategies and have increased in parallel with the development of computer technology. Particularly in developed countries, multi-purpose decision-making methods and analyses are being used in studies. These include the comparison of forest planning and management strategies (Teeter \& Dyer 1986; Hyberg 1987; Zinkhan \& Zinkhan 1994; Stevens et al. 2000), the determination of multi-dimensional benefiting principles (Zinkhan \& Holmes 1997; Sayadi et al. 2000), the prioritization of nature tourism or eco-tourism activities (Morimoto 1999; Suh \& Gartner 2004), the designation of the value of natural resources and the detection of damage to those resources (Matnews et al. 1995; Holmes et al. 1996; Holmes et al. 1998), and an assessment of the value of forest products and services without a market (Mackenzie 1993; Gan \& Luzar 1993; Adamowicz et al. 1994).

As is the case in Turkey, protected areas in developing countries encounter problems, such as false and unplanned land use, high population increases and multidirectional demands for scarce resources, poor rural populations, inadequate or lacking institutional support, insufficient education or consciousness, in addition to visitors pressure (Başal 1998; Ünal et al. 2007; Kuter 2008; Ayan et al. 2009).

The study aimed to identify the best management alternative for leaving these conservation value areas to future generations and raising the awareness of decision makers and users. Within this scope many factors and alternatives should be considered in deciding on the best management model and the chosen alternatives must be evaluated according to these factors. For this purpose Analytic Hierarchy Process (AHP) was used, a multi-factored decision-making technique which considers hierarchy. It is targeted at increasing the environmental consciousness of the decision makers and users, focusing the attention on the potentials of the areas and featuring the principle of long-term sustainability.

\section{Study site and method}

The study took place in Ilgaz Mountain National Park (IMNP). The national park (NP) is located in one of the mountains in the western section of the Black Sea Region, within the boundaries of the provinces of Kastamonu and Çankırı (Figure 1). An area of 1088 hectares was proclaimed a NP on 2 June 1976. It is managed by the IMNP branch directorate associated with $11^{\text {th }}$ Regional Directorate of the General Directorate of Nature Protection and National Parks under the National Park Act number 2873.

The research was based on the factors of natural values and cultural values, factors that affect the NP ecosystem negatively and NP objectives and policies. The sub-factors are defined as follows:

\section{Natural values factors}

Natural landscape elements of the NP are composed of edaphic (soil, geology, hydrology etc.) and physiographic elements (area size, slope), climate and 

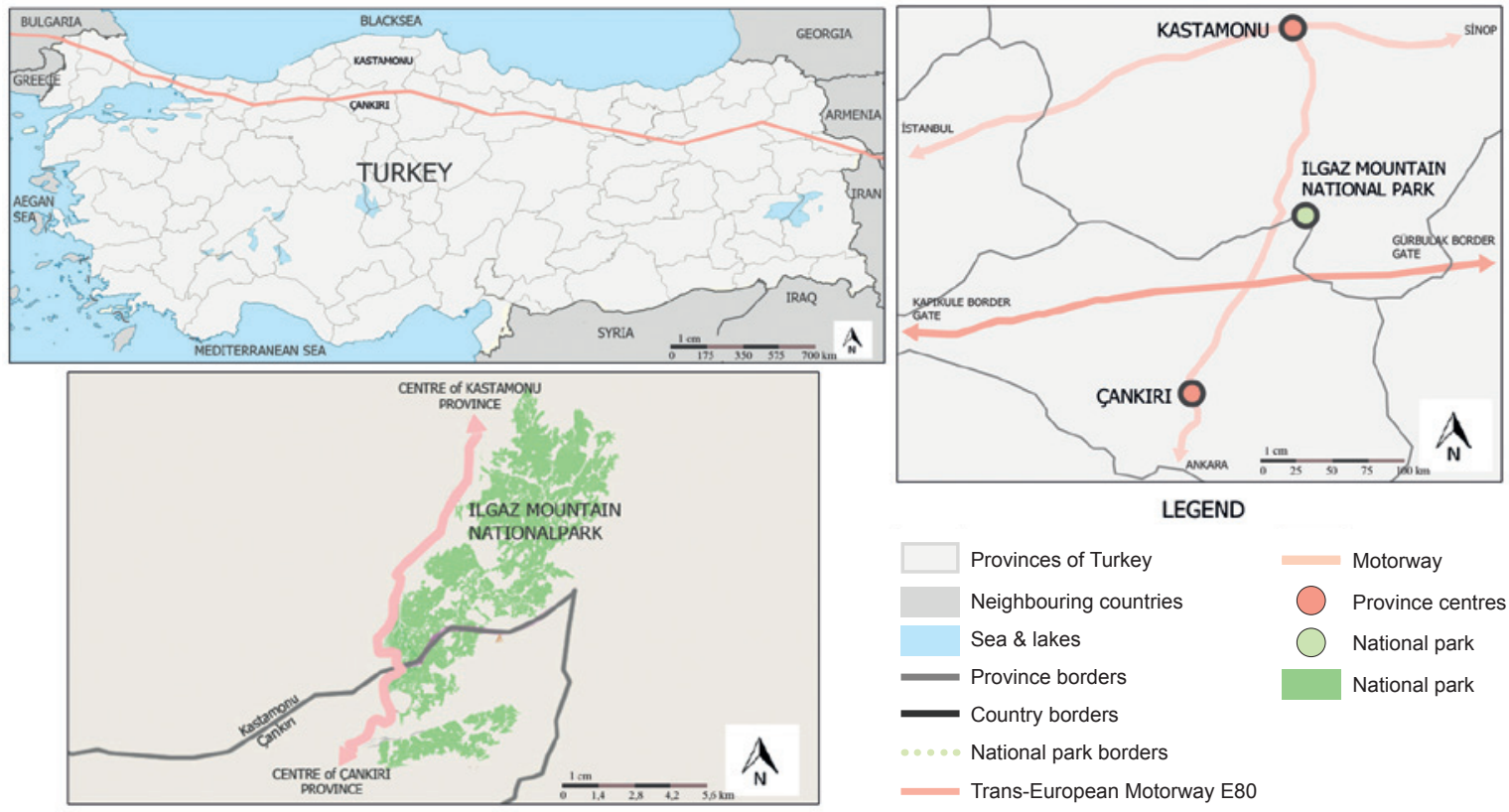

LEGEND

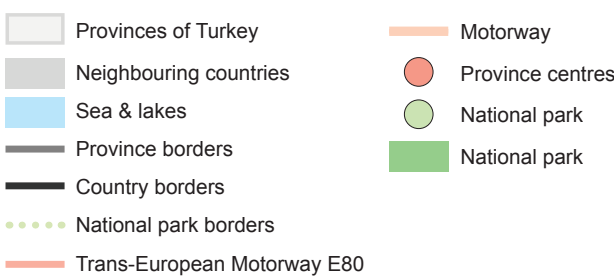

Figure 1 - Location of IMNP. Map created with data taken from Aydinözü et al. 2012. (C) OpenStreetMap contributors, UBAK

flora-fauna. The area is composed of valleys with different characters, steep slopes, hillsides and crests. The slopes in the study area are fairly steep in general (88\%) (Soil Survey Staff 1999). The most significant rivers of the area are called Karanlık and Baldıran. Besides these, there are tributaries of the Kizilayak stream and the Big Stream (LTDP 2008). According to Soil Survey Staff (1999), the land is classified as Class VII land-use capacity (Province of Kastamonu Land Asset 1993 / Province of Çankırı Land Asset 1998). According to Soil Survey Staff (1999), third degree (937 ha) and fourth degree (152 ha) soil erosion was observed within the boundaries of the NP (Aydınözü et al. 2009).

The land structure of IMNP, located in the transition strip from North Anatolia to Central Anatolia, is generally composed of serpentines, schists and volcanic rocks. Mountains are composed of metamorphic rocks belonging to the Palaeozoic era (Menteş 2001). Northern hillsides of the area are under the influence of oceanic climates and the southern sections are under the influence of a cold, semi-arid Mediterranean climate (LTDP 2008; Akman 1990).

The area is located in the Auxin section of the Euro-Siberian main flora region. The forest ecosystem in the NP is composed of Abies nordmanniana (Stev.) Spach. subsp. bornmülleriana Mattf. and Pinus sylvestris L. (Kalıpsiz 1988). Southern aspects of the NP have wider meadow areas than the north. Two hundred and thirty-four taxa belonging to 51 families were detected in the area. Thirty-seven of those taxa are endemics special to Turkey. Four of those endemics spread only in Ilgaz Mountain. Of those species, Arabis abietina and Barbarea trichopoda are found in the IUCN Red List Category Critical (CR); Corydalis wendelboi subsp. congesta and Ornithogalum wiedemannii var. reflexum in the Category Endangered (EN) (Table 1) (LTDP 2008).
The NP area has a rich wildlife. The forest ecosystem contains vertebrate fauna elements, brown bear (Ursus arctos), wolf (Canis lupus), red fox (Vulpes vulpes), common pipistrelle (Pipistrellus pipistrellus), European hare (Lepus europaeus), red squirrel (Sciurus vulgaris), common buzzard (Buteo buteo), black kite (Milvus migrans), Egyptian vulture (Neophron percnopterus), cinereous vultures (Aegypius monachus), shorttoed snake-eagle (Circaetus gallicus), northern goshawk (Accipiter gentilis), long-legged buzzard (Buteo rufinus), golden eagle (Aquila chrysaetos), booted eagles ( $\mathrm{Hi}$ eraaetus pennatus), griffon vulture (Gyps fulvus), and eastern imperial eagle (Aquila heliaca). Moreover, the area is located in a migration path. In total, 34 bird species were detected in the area, 31 of which are under protection within the scope of the Berne Act (LTDP 2008).

\section{Cultural values factors}

IMNP is on the Trans-European Motorway E80 of Ankara-Çankırı-Kastamonu, which runs $40 \mathrm{~km}$ from the province of Kastamonu and $80 \mathrm{~km}$ from the province of Çankırı. There are eight accommodation facilities serving tourism purposes in the NP area and in neighbouring places. Those facilities have 450 rooms and a capacity of 1400 beds. The park area, which is visited annually by an average of 30000-50000 visitors, is very significant in terms of responding to the recreational demands of the region (Kastamonu Provincial Directorate of Culture and Tourism 2012). The $\mathrm{NP}$ area is very popular in terms of winter tourism. It is also suitable for recreational activities including botanic trips, trekking, bicycle tours, mountain climbing, running, photo-safaris, monitoring wildlife, picnics, as well as camping in spring, summer and autumn (Öztürk \& Aydoğan 2012). 
Table 1 - Endemism statuses and IUCN Red List Categories of plant species in IMNP

\begin{tabular}{|c|c|c|c|}
\hline Total number of taxa in IMNP & \multicolumn{2}{|c|}{ Number of endemic taxa in IMNP } & Endemism proportion (\%) \\
\hline 234 & \multicolumn{2}{|c|}{37} & 15.8 \\
\hline \multicolumn{4}{|c|}{ Red List Categories in IMNP } \\
\hline Critical (CR) & Endangered (EN) & Vulnerable (VU) & Low critical (LC) \\
\hline 2 & 3 & 4 & 225 \\
\hline
\end{tabular}

The total population of the area within the boundaries of the provinces of Kastamonu and Çankır1 (Kastamonu 313636, Çankırı 157 874) is 471510 (Tüik 2013). In examining the economy in the vicinity of the NP, it was observed that climate, nature and land conditions create significant limitations. For this reason agricultural output is inadequate. In most of the rural settlements neighbouring the national park the major source of income is forestry. There is also an agricultural development cooperative, established in 1976.

\section{Factors affecting the NP ecosystem negatively}

The fact that the NP is located in a transition region in terms of climate means that intense local snow and storms create increased windbreak damage. Such damage is further exacerbated by wide-spread disease in old conifer forests, e. g. cancer, witch broom, hardwood rot and rot of the main root (Sivacioğlu et.al. 2007). Şimşek et.al. (2003) reported three testacean insect species in overturned and erected fir trees $(\mathrm{Cry}$ phalus picea, Pityokteines curvidens, Ips acuminatus) in their examination and control report. There were further factors that weaken the trees and make them vulnerable to testacean insects, including fir cancer (Melampsorella caryopyllacearum) and mistletoe (Viscum album L. subsp. abietis (Wiesb.) Abromeit).

There are three mechanical ski facilities in the study area. Facility number 1 was constructed in 1985, number 2 was constructed in 1996, and number 3 was constructed in 2011. Severe soil erosion on the surface of track number 1 has severely corrupted the natural landscape character and damaged plant formation. Furthermore, those tracks fail to respond to the number of visitors increasing gradually every year. For this reason the construction of the fourth track continues. The accommodation facilities located in the study area have a structure that is not in harmony with the natural characteristics of the NP in terms of both their positions and architectural characteristics. Therefore intense visitor stress and the buildings constructed to address it harm the biodiversity and visual quality of the NP.

\section{NP objectives and policies}

For protecting, increasing and sustaining the resource values of NPs, the technical, managerial, social and economic targets and policies must be determined. IMNP has three different ecosystem regions; forest, clearings and grasslands. But the inadequately planned forest roads, parking lots, mechanical facilities for the ski-runs and the hotel areas are causing the disruption of these ecosystem regions. In terms of the harmony of the area, these constructions are not suitable with their mass, location, density and structural properties (Kuter 2008). Such use, which also harms the aesthetic and visual quality of the NP, also affects the natural tourism negatively, which is central to rural development. In 2007 the Long Term Development Plan (LTDP) was created to satisfy the touristic and recreational needs with a good management plan, but it exists in name only.

\section{Method}

The Analytical Hierarchy Process was developed by Thomas H. Saaty in 1977. It is one of the most comprehensively designed systems for decision making with different factors. The technique provides a formulation of the problems in a hierarchical manner and it can consider different quantitative and qualitative criteria of the problem. This process allows entering the different choices of decision-making and facilitates the process of sensitivity analysis of each factor (Babaeinesami \& Abdi 2012).

The evaluation data of plant location suitability for various subjective factors and the weights of each factor are usually expressed in linguistic terms. In addition, to efficiently resolve the ambiguity frequently arising from available information and to do more justice to the essential fuzziness in human judgment and preference, the AHP set theory has been used to clarify ill-defined multiple-criteria decision-making problems (Akpinar 1995; Safari et al. 2012; Liang 1999). The AHP technique, mainly as a binary comparison of the elements derived from the theory of measurement, is based on the priority value. The AHP technique is carried out in four stages (Zahedi 1986).

\section{Step 1}

A decision hierarchy is established from the decision elements which define the decision-making problem. In this study, the established hierarchy consisted of: the objective, factors, sub-factors and alternatives.

\section{Step 2}

The priorities are determined binary comparison. In pairwise comparisons, decision makers are asked to answer questions like: "According to a top level element, when element 1 and element 2 are compared, which element is preferable (more important)?" and "How much more is the chosen element preferred to the other element?" Pairwise comparisons scaled in the technique are within the range 
Table 2 - Pairwise comparison scale used for preferences in AHP technique.

\begin{tabular}{|l|c|c|c|c|c|c|}
\hline Verbal statements & Equal & Partially & Quite & Strongly & Definitely & Interval values \\
\hline Numerical & 1 & 3 & 5 & 7 & 9 & $2,4,6,8$ \\
\hline
\end{tabular}

of 1 to 9 (Table 2) (Saaty 1990). In AHP the opinions are transferred into a matrix. If aij symbolizes the pairwise comparison value of $i$ feature and $j$ feature, it is derived from the equation of aji=1 / aij. This attribution is called correspondence (Saaty 1980; Saaty 1994).

$\mathrm{W}=\left[\mathrm{W}_{1}, \mathrm{~W}_{2}, \ldots, \mathrm{W}_{\mathrm{n}}\right]$

\section{Step 3}

By using the eigenvector value, the relative priority values (importance, weightiness) of the decision elements are determined. This method is important in terms of providing a measure on the consistency of paired comparison results. The eigenvector which is equal to the highest eigenvalue $\left(\lambda_{\max }\right)$ of the pairwise comparison matrix is equal to the priority vector which is illustrated as follows.

Since pairwise comparisons performed while calculating the importance or priority values of elements depending on pairwise comparisons matrix are based on subjective grounds, mistakes or inconsistencies may arise in AHP technique. A Consistency Proportion is used in the AHP technique for measuring this situation.

For calculating the consistency in pairwise comparisons, AHP recommends the following process:

$\mathrm{CR}=\frac{\mathrm{Cl}}{\mathrm{RI}}$

with $\mathrm{CR}=$ consistency rate, $\mathrm{CI}=$ consistency index, $\mathrm{RI}=$ random index. If the resulting $\mathrm{CR}$ is less than 0.10 , it means that the comparison is consistent. If the CR value is greater than 0.10 , it points to a miscalculation in the AHP, or the comparison is inconsistent.

\section{Step 4}

This is the stage of general priority values determination. To this end the general priority values of the elements of the lower levels (decision alternatives) in the decision hierarchy are determined according to the top-level general objective process. The overall priority values and ranking of decision alternatives is obtained according to the relative priority values of the decision elements. The priority values of the decision alternatives according to the general objectives are obtained by multiplying the priority values of every element in the second level of hierarchy with the priority values of the related third-level elements, and finally by collecting these weighted alternative values.

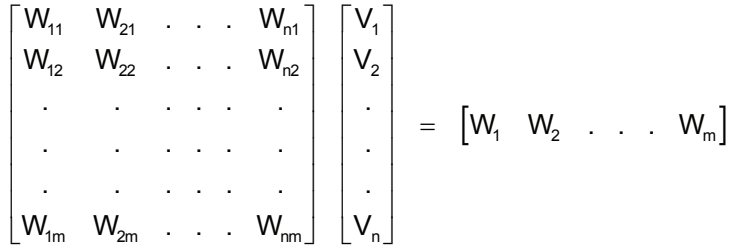

The process of determining suitable management alternatives

First, a relation of purpose, factor and hierarchy was established using the AHP method. Factor, sub-factor and alternatives were determined for comparison matrix tables and a hierarchical structure was created. Within this scope, four fundamental factors composed of natural values factors, cultural values factors, negative factors affecting the NP ecosystem, and NP objectives and policies factors were discussed in the study. Among those factors, natural values factors were composed of the sub-factors of physiographic aspects (area size, slope), edaphic aspects (soil, geology, hydrogeology), climate, and flora-fauna. Cultural values factors were composed of population, economy, tourism and transportation. Factors affecting the NP ecosystem negatively were composed of insect-fungus damage, visitor pressure and wind-snow damage, while NP objectives and policies factors were composed of preservation of the ecosystem, tourism and recreation demand, and rural development. Three alternatives were developed within the method and were targeted at preferring the most convenient alternative, considering all factors and sub-factors. These were Alternative A: Absolute Protection, Alternative B: Use with Protection Priority, and Alternative C: Protection with Use Priority (Figure 2). The pairwise comparison necessary for prioritizing factor, sub-factor and alternatives in the hierarchical structure was performed by a group of experts who knew the area.

\section{Findings}

National parks which have natural, cultural, recreational resources and rare beauty are the most important natural areas to leave to future generations. At the same time these areas are important rural development tools for the inhabitants. To determine the rational and appropriate management alternative for such an area, the AHP method was used. A comparison and the evaluation of decision alternatives were carried out on each factor, sub-factor and general objective. In the AHP method, pairwise comparison of all factors was performed in the study. Such a pairwise comparison was carried out for natural values factors, cultural values factors, negative factors affecting the NP ecosystem, and NP objectives and policies. Each factor was compared with three other factors, in other words, each of them was 
Table 3 - Pairwise comparison of qualitative factors, natural and cultural factors, negative aspects that affect the ecosystem, and factors that affect national park objectives and policies.

\begin{tabular}{|l|c|c|c|c|c|}
\hline Factors & NVF & CVF & NFANPE & NPOP & Eigenvector \\
\hline Natural values factors (NVF) & 1 & 3 & 0.5 & 0.33 & 0.1607 \\
\hline Cultural values factors (CVF) & 0.33 & 1 & 0.2 & 0.14 & 0.0596 \\
\hline $\begin{array}{l}\text { Negative factors affecting NP } \\
\text { Ecosystem (NFANPE) }\end{array}$ & 2 & 5 & 1 & 0.5 & 0.2870 \\
\hline NP objectives and policies (NPOP) & 3 & 7 & 2 & 1 & 0.4927 \\
\hline
\end{tabular}

\begin{tabular}{|l|c|c|c|c|}
\hline Comparison of natural factors \\
\hline Factors & E & P & C & F-F \\
\hline Edaphic (E) & 1 & 0.5 & 0.5 & 0.33 \\
\hline Physiographic (P) & 2 & 1 & 1 & 0.5 \\
\hline Climate (C) & 2 & 1 & 1 & 1 \\
\hline Flora-Fauna (F-F) & 3 & 2 & 1 & 1 \\
\hline
\end{tabular}

\begin{tabular}{|c|c|c|c|c|c|}
\hline \multicolumn{6}{|c|}{ Weighted points and priorities of management alternatives according to natural factors } \\
\hline \multirow{2}{*}{ Factors } & \multicolumn{3}{|c|}{ Alternatives } & \multirow[t]{2}{*}{ Eigenvector } & \multirow{2}{*}{$\begin{array}{c}\text { Consistency } \\
\text { rate }\end{array}$} \\
\hline & (A) & (B) & (C) & & \\
\hline Edaphic & 0.30 & 0.54 & 0.16 & 0.1237 & 0.005 \\
\hline Physiographic & 0.60 & 0.30 & 0.10 & 0.2185 & 0.003 \\
\hline Climate & 0.31 & 0.59 & 0.11 & 0.2745 & 0.008 \\
\hline Flora-Fauna & 0.48 & 0.40 & 0.12 & 0.3833 & 0.000 \\
\hline$\mu$ qualitative & 0.5816 & 0.3090 & 0.1095 & 1 & \\
\hline
\end{tabular}

\begin{tabular}{|l|c|c|c|c|}
\hline Comparison of cultural factors \\
\hline Factors & Pop & Ec & T & Tr \\
\hline Population (Pop) & 1 & 0.2 & 0.14 & 0.33 \\
\hline Economy (Ec) & 5 & 1 & 0.5 & 2 \\
\hline Tourism (T) & 7 & 2 & 1 & 3 \\
\hline Transportation (Tr) & 3 & 0.5 & 0.33 & 1 \\
\hline
\end{tabular}

\begin{tabular}{|c|c|c|c|c|c|}
\hline \multicolumn{6}{|c|}{ Weighted points and priorities according to cultural factors } \\
\hline \multirow{2}{*}{ Factors } & \multicolumn{3}{|c|}{ Alternatives } & \multirow{2}{*}{ Eigenvector } & \multirow{2}{*}{$\begin{array}{c}\text { Consistency } \\
\text { rate }\end{array}$} \\
\hline & (A) & (B) & (C) & & \\
\hline Population & 0.30 & 0.54 & 0.16 & 0.0595 & 0.005 \\
\hline Economy & 0.16 & 0.30 & 0.54 & 0.2872 & 0.007 \\
\hline Tourism & 0.16 & 0.54 & 0.30 & 0.4917 & 0.007 \\
\hline Transportation & 0.16 & 0.54 & 0.30 & 0.1616 & 0.007 \\
\hline Mqualitative & 0.1707 & 0.4706 & 0.3588 & 1 & \\
\hline
\end{tabular}

\begin{tabular}{|l|c|c|c|}
\hline Negative factors affecting the NP ecosystem \\
\hline Factors & IFH & VP & SSD \\
\hline Insect fungus damage (IFH) & 1 & 0.5 & 3 \\
\hline Visitor pressure (VP) & 2 & 1 & 5 \\
\hline Storm snow damage (SSD) & 0.33 & 0.2 & 1 \\
\hline
\end{tabular}

\begin{tabular}{|c|c|c|c|c|c|}
\hline \multicolumn{6}{|c|}{ Weighted points and priorities according to negative factors affecting the NP ecosystem } \\
\hline \multirow{2}{*}{ Factors } & \multicolumn{3}{|c|}{ Alternatives } & \multirow[t]{2}{*}{ Eigenvector } & \multirow{2}{*}{$\begin{array}{c}\text { Consistency } \\
\text { rate }\end{array}$} \\
\hline & (A) & (B) & (C) & & \\
\hline Insect fungus damage & 0.30 & 0.54 & 0.16 & 0.3090 & 0.008 \\
\hline Visitor pressure & 0,16 & 0.30 & 0.54 & 0.5816 & 0.007 \\
\hline Storm snow damage & 0.30 & 0.54 & 0.16 & 0.1095 & 0.008 \\
\hline$\mu$ qualitative & 0.2189 & 0.3983 & 0.3829 & 1 & \\
\hline
\end{tabular}

\begin{tabular}{|l|c|c|c|}
\hline NP objectives and policies & PE & DTR & RD \\
\hline Factors & 1 & 2 & 5 \\
\hline Protection of the ecosystem (PE) & 0.5 & 1 & 3 \\
\hline Demand of tourism and recreation (DTR) & 0.2 & 0.33 & 1 \\
\hline Rural development (RD) & &
\end{tabular}

\begin{tabular}{|l|c|c|c|c|c|}
\hline \multirow{2}{*}{ Weighted points and priorities according to factors of NP objectives and policies } \\
\cline { 2 - 6 } & \multicolumn{3}{|c|}{ Alternatives } & Eigenvector & $\begin{array}{c}\text { Consistency } \\
\text { rate }\end{array}$ \\
\hline Protection of the ecosystem & 0.58 & 0.30 & 0.10 & 0.5816 & 0.003 \\
\hline Demand of tourism and recreation & 0.14 & 0.57 & 0.29 & 0.3090 & 0.000 \\
\hline Rural development & 0.10 & 0.58 & 0.30 & 0.1095 & 0.004 \\
\hline$\mu$ qualitative & 0.3943 & 0.4199 & 0.1858 & 1 & \\
\hline
\end{tabular}




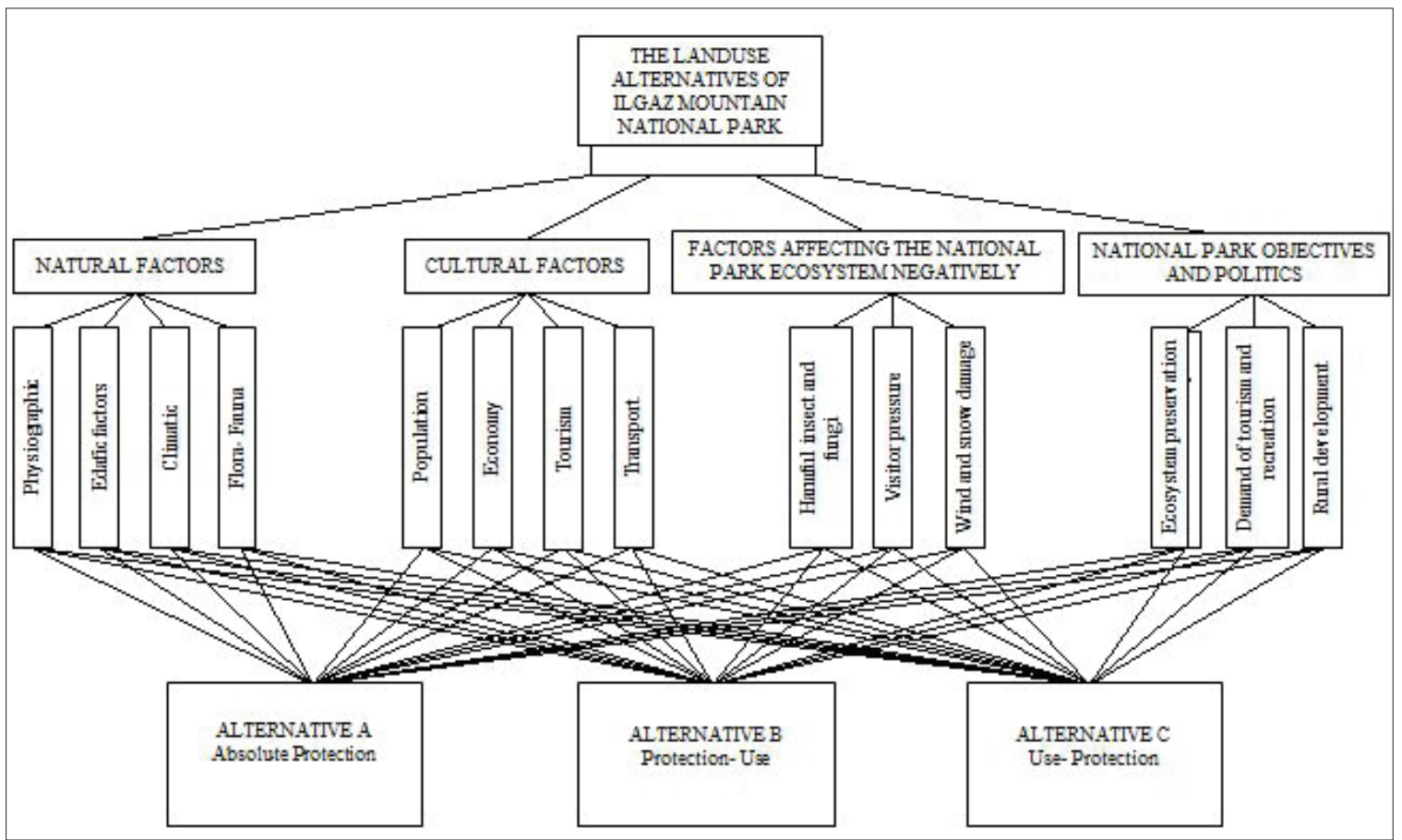

Figure 2 - AHP structure

compared with each other in a binary way. According to these pairwise comparisons and AHP results, NP objectives and policies were chosen as the most primarily preferred factors with the highest rate of 0.49 . The least primarily preferred factor was cultural values factors with a rate of around 0.06. Protection of the ecosystem (PE) was chosen as the most primarily preferred sub-factor of NP Objectives and policies. Here, the most convenient alternative was revealed as Absolute Protection (A) (0.5816) for natural factors, alternative Protection-Use (B) (0.4706) for cultural factors, alternative Protection-Use (B) (0.3983) for factors affecting the NP ecosystem negatively, and alternative Protection-Use (B) (0.4199) for factors affecting NP objectives and policies (Table 3).

This situation proves that, according to the natural values factors, absolute protection must be a priority for sustaining the existing source values. But according to the cultural values factors, the factors affecting the ecosystem negatively, the factors affecting the NP objectives and policy and sub-factors of these factors, the alternative Protection-Use was prioritized at a high level.

This suggests that it is necessary to offer the user the potential values permitted for human use while paying attention to ecological balances, and to asses planning and management decisions from this point of view.

When the alternatives are assessed according to all qualitative factors, Protection-Use (B) ranks first as the most important alternative with a value of 0.3903 , Absolute Protection (A) ranks second with a value of (0.3605), and Use-Protection (C) appears as the least important alternative with a value of (0.2401) (Table 4). In this case, the most suitable alternative for IMNP is Protection-Use (B).

\section{Discussion and conclusion}

Suitability of the techniques used in management and planning studies has significance particularly for practitioners. In recent years it was admitted that it is necessary to provide participation in many planning and management steps. It was specifically stipulated as a national policy to prepare the large-scale Long Term Development Plan (LTDP), because NP areas encounter human demand stress including from recreational and touristic facilities and that the protection of resources becomes difficult. LTDP was prepared in 2008 in coordination with the public, interest and pressure groups, and multidisciplinary experts under the management of land, forest resources in IMNP. The decisions taken within this plan benefited from the AHP technique used in the study. The following results emerged in the study of the selection of the best use alternatives in the IMNP sample of the AHP technique:

In the comparison of qualitative factors, factors regarding area use objectives and policies (0.4927) emerged as the high-priority factor. The least significant factor was the cultural factor (0.0596).

In the comparison of natural factors, flora and fauna $(0.3833)$ was the most indicative factor. The least significant factor was the edaphic factor. Depending on these, considering all natural factors, the Absolute Protection alternative was the most suitable with a value of 0.5816 . In particular, the effect of diversity of endemic plants and wildlife of the area emerged here.

As a result of the comparison of cultural factors, it was revealed that tourism (0.4917) was the factor with the most effect on the NP area and the population factor $(0.0595)$ was the factor with the least effect. Con- 
sidering all cultural values, the Protection-Use (0.4706) model came to the fore. However, the tourism form to be developed in the area is ecotourism. It was stipulated that it is essential in NP management to allow uses and developments provided by protection-use balance rather than providing the highest earning form. In this case attention is drawn to the fact that the tourism factor is one of the priority issues to be considered.

When factors affecting the NP ecosystem negatively are compared, it was revealed that visitor pressure $(0.5816)$ was the high priority factor for the area. It was determined that wind and snow damage had the least effect with 0.1095 . Considering all those factors, the Protection-Use (0.3983) alternative came to the fore. The fact that the area has potential resource values that would attract visitors exposes the area to visitor pressure. In addition to the emergence of the tourism potential among cultural factors, visitor pressure is found to be the factor that most affects the ecosystem. The fact that the NP creates potential in terms of tourism, particularly winter tourism, reveals the need for effective management and a management plan that would provide sustainability in the long run.

Considering the factors regarding NP objectives and policies, preservation of the ecosystem emerged as the high priority factor with 0.5816 and the Rural development factor with 0.1095 . When all those factors are considered, the Protection-Use alternative emerged as the most significant factor with 0.4199 .

When all qualitative factors were considered, it was revealed that the most suitable area use alternative was Alternative B (0.3903): Protection-prioritized Use. A management alternative supported by protectionprioritized use emerges in the study when all installed factors and sub-factors are taken into consideration.

The study suggests a management method which emphasizes sustainability of resource values, permits certain uses in conformity with visitor carrying capacity and allows participation. Protection-prioritized decisions, which pay attention to perceptional diversity on a landscape ecology basis and which consider user demand on a sub-scale, shall be realized only in this manner. Preparation of a detailed LTDP plan, which is a large-scale plan itself, with an ecological approach for the subordinate plans (visitor management plan, sustainable tourism strategy plan, habitat management plan, etc.) becomes significant at that point. Through these sub-plan decisions the area is divided into zones (absolute protection zone, buffer zone, rehabilitation zone etc.) and protection and use balance of landscape values shall be provided. It is believed that all those results and suggestions shall carry IMNP to a management that provides protection focused on rational use within a sustainable development understanding.

\section{Acknowledgements}

We would like to thank Prof. Dr. Nevin Akpinar, faculty member of Ankara University, Agriculture
Table 4-Assessment of alternatives according to all qualitative factors. * multiplication

\begin{tabular}{|c|c|c|c|c|c|c|c|}
\hline \multirow{5}{*}{ 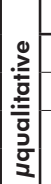 } & NVF & CVF & NFANPE & NPOP & \multirow{5}{*}{ * } & Eigenvector & Alternatives \\
\hline & 0.5816 & 0.1707 & 0.2189 & 0.3943 & & 0.1607 & 0.3605 \\
\hline & 0.3090 & 0.4706 & 0.3983 & 0.4199 & & 0.0596 & 0.3903 \\
\hline & 0.1095 & 0.3588 & 0.3829 & 0.1858 & & 0.2870 & \multirow{2}{*}{0.2401} \\
\hline & 0.1073 & 0.3500 & 0.3029 & 0.1050 & & 0.4927 & \\
\hline
\end{tabular}

Faculty, Department of Landscape Architecture for her contributions to the statistical analysis section of the study.

\section{References}

Adomowicz, W., J. Louviere \& M. Williams 1994. Combining Revealed and Stated Preference Methods for Valuing Environmental Amenities. Journal of Environmental Economics and Management 26: 271-292.

Akman, Y. 1990. Climate and Bio-climate (Bio-climate Methods and Turkey Climates). Ankara.

Akpinar, N. 1995. A research on: The utilisation possibilities of fuzzy set technics during the evaluation of post mining lands application alternatives. Ankara University Faculty of Agriculture Publications 1430 (793): 38.

Ayan, S., N. Akpınar, S. Öztürk, N. Belkayalı, H. Şevik, A. Kalayc1, S. Acar \& C. Berber 2009. The evaluation of the management alternatives of Ilgaz. Mountain $\mathrm{Na}$ tional Park. International Conference on Plants and Environmental Pollution (ICPEP-2009). Erciyes University 6-11 July 2009. Kayseri, Turkey.

Aydınözü, D., Ü. İbret \& M. Aydın, 2012. Analysis of Terrain Usage in Kastamonu-Ilgaz Mountain National Park, Journal of Marmara Geography 26: 108-123.

Babaeinesami, A. \& F. Abdi 2012. Comparison and Grade Analysis Of The Effective Criteria in Organizational Learning by Hierarchical Analysis (AHP). African Journal of Business Management 6 (9): 3181-3187.

Başal, M. 1998. Naturalgas-Yapracik Facilities Land Use Planning. Scientific Investigations and Researches: 602. Ankara University, Faculty of Agriculture Individual Researches Publication 1104.

Gan, C. \& E.J. Luzar 1993. A Conjoint Analysis of Waterfowl Hunting in Louisiana. Journal of Agricultural and Applied Economics 25: 36-45.

Holmes, T., K. Alger, C. Zinkhan \& E. Mercer 1998. The Effect of Response Time on Conjoint Analysis Estimates of Rainforest Protection Values. Journal of Forest Economics 4 (1): 7-28.

Holmes, T., C. Zinkhan, K. Alger \& E. Mercer 1996. Conjoint Analysis of Nature Tourism Values in Bahai Brazil. The Forestry Private Enterprise Initiative Working Paper 57: 19.

Hyberg, B.T. 1987. Multi Attribute Decision Theory and Forest Management: A Discussion and Application. Forest Science 33: 835-845.

Kastamonu Provincial Directorate of Culture and Tourism 2012. Ilgaz. Mountain National Park Tourism Facilities Bed Capacities Data. Kastamonu, Turkey. 
Kuter, N. 2000. Assessment of Ilgaz Mountain National Park in Terms of Forest Landscape and Aesthetics. Journal of Süleyman Demirel University Faculty of Forestry 1: 36-47. Isparta.

Liang, G.S. 1999. Fuzzy MCDM Based on Ideal And Anti-Ideal Concepts. European Journal of Operational Research. 112: 682-691.

LTDP 2008. Long Term Development Plan of Ilgaz Mountain National Park. Analysis Scrutiny Report. Kastamonu.

Mackenze, J. 1993. A Comparison Of Contingent Performance Models. American Journal of Agricultural Economics 75: 593-603.

Matnews, K.E., F.R. Johnson, R.W. Dunford \& W.H. Desvousges 1995. The Potential Role Of Conjoint Analysis In Natural Resource Damage Assessment. Triangle Economic Research Technical Working Paper. G-9503: 1-18.

Menteş, İ. 2001. Investigation and Management of Ilgaz Mountain National Park as a Protected Area. Doctorate Thesis. Black Sea Technical University, Institute of Science and Technology. Trabzon.

Morimoto, S. 1999. A Stated Preference Study to Evaluate the Potential for Tourism in Luang Prabang, Laos. Graduate School of International Cooperation Studies, Kobe University. Japan.

OpenStreetMap 2014. http://www.openstreetmap. org $/ \#$ map $=11 / 41.0724 / 33.8180$ \&layers $=Q N$

Öztürk, S. \& A. Aydoğdu 2012. Recreational Facilities of Ilgaz Mountain National Park. I. Recreation Researches Congress 611-628. Kemer, Antalya.

Özbay, S. 2008. Planning Studies in Nature Protection Areas and Ayvalık Islands Natural Park. Management Plan Proposal. ITU, Institute of Science and Technology. Istanbul.

Province of Çankırı Land Asset 1998. Republic of Turkey, Prime Ministry, General Directorate of Rural Services. Ankara, Turkey.

Province of Kastamonu Land Asset 1993. Republic of Turkey, Prime Ministry, General Directorate of Rural Services. Ankara, Turkey.

Saaty, T.L. 1980. The Analytic Hierarcy Process. New York, McGraw-Hill.

Saaty, T.L. 1990. How to Make a Decision: The Analytic Hierarchy Process. European Journal of Operations Research 48: 9-26.

Saaty, T.L. 1994. How to Make a Decision: The Analytic Hierarchy Process. Interfaces 24 (6): 19-43.

Safari, H. A. Faghih \& M.R. Fathi 2012. Fuzzy Multi-Criteria Decision Making Method for Facility Location Selection. African Journal of Business Management 6 (1): 206-212.

Sayadi, S., M.C. Gonzalez \& J. Calatrava 2000. Ranking Versus Scale Rating In Conjoint Analysis: Evaluating Landscapes in Mountainous Regions in Southeastern Spain. Ecological Economics 55 (4): 539-550.

Sivacioğlu, A., S. Ayan \& N. Öner 2007. Effect of Silvicultural Application On The Stand Structure in Fir Forest of Mounts Ilgaz and The Environment. National Environment Symposium. Mersin University.

Soil Survey Staff 1999. Soil Taxonomy. A Basic of Soil Classification for Making and Interpreting Soil Survey. USDA Handbook 436, Washington D.C.

Stevens, T.H., R. Belkner, D. Dennis, D. Kittredge \& C. Willis 2000. Comparison of Contingent Valuation and Conjoint Analysis in Ecosystem Management. Ecological Economics. 32: 63-74.

Suh, Y.K. \& W.C. Gartner 2004. Preferences and Trip Expenditures - A Conjoint Analysis of Visitors to Seoul, Korea. Tourism Management 25: 127-137.

Şimşek, Z., S. Ünal, M. Yamantaş, Ö. Şahin, M. Tarhanl, Y. Gün, E. Kapdan, M. Uçukoğlu, M.S. Ay \& I. Yazar 2003. Report on Examination and Assessment of Report of Extraordinary Revenue in Ilgaz. Mountain $\mathrm{Na}$ tional Park. Kastamonu, Turkey.

Teeter, L.D. \& A.L. Dyer 1986. A Multi Attribute Utility Model for Incorporating Risk in Fire Management Planning. Forest Science 31: 1032-1048.

TÜİK (Turkey of Statistical Agency) 2013. Kastamonu and Cankir 2012. Address Based Population Data.

UBAK, nd. International Road Projects. http:// www.ubak.gov.tr/BLSM_WIYS/UBAK/en/enhtml/20090819_142036_204_2_64.html. (accessed $01.09 .2014)$

Ünal, S., A. Sivacioğlu, S. Ayan \& N. Öner 2007. Storm Turndowns and Entomological Results in Ilgar Mountain Forests. National Environmental Symposium. Mersin.

Zahedi, F. 1986. The Analytic Hierarchy Process - A Survey of the Method and its Applications. Interfaces 16: 96-108.

Zinkhan, F.C. \& T.P. Holmes 1997. Conjoint Analysis: A Preference-Based Approach for The Accounting of Multiple Benefits in Southern Forest Management, Economics of Forest Protection and Management Research Unit, Research Triangle Park. SJAF 21 (4): 180-186.

Zinkhan, F.C. \& G.M. Zinkhan 1994. An Application of Conjoint Analysis to Capital Budgeting: The Case of Innovative Land Management Systems. Managerial Finance 20 (7): 37-50.

\section{Authors}

\section{Sevgi Öztürk}

Kastamonu University, Faculty of Engineering and Architecture, Department of Landscape Architecture Kastamonu, Turkey.

Email:sozturk@kastamonu.edu.tr

\section{Sezgin Ayan}

Kastamonu University, Faculty of Forestry, Forest Engineering Department, Kastamonu, Turkey.

Email: sezginayan@kastamonu.edu.tr 